\title{
Fungi: Too evolved to be condemned
}

\author{
Manu Kothari, Atul Goel* \\ Departments of Anatomy and *Neurosurgery, King Edward Memorial Hospital \& Seth G.S. Medical College, Parel, Mumbai, India
}

The word fungus has an interesting etymology, being sfungus $=$ sponge, one with many pores. Homer's Odyssey (1050-850 B.C.) refers to the 'many-pored sponges'. So, porous, sporous, spongous, sfungus, fungus. The white mold on your brown bread is porous and foretells you of the porosity of the bread that is fungal in origin. The science of fungi isn't fungology but mycology, from Gk. mycos = fungus or mushroom. The science of mycology dates back to 1677 when Hooke, a contemporary of Newton and the first to microscopically describe and name a 'cell', discovered that the yellow spots on rose-leaves consisted of filamentous fungi, the study of which he started. Saccardo, in 1906, published an 18-volume Sylloge fungorum, carrying an account of 57,660 fungi, a figure crossing 150,000 as of today. The whole antibiotic era started with the fungus Penicillum notatum that favored Fleming, Florey and Chain with a Nobel prize.

Let us count the blessings first: Fungi mean money, business, and quality life. They bake our bread, brew our wine, swell the idlis and dhoklas, spread the dossay, offer you n number of antibiotics and even immunosuppressives, and above all, desist from harming the humans. They help humans to turn into fun-guy and fun-gal revelers. Of the nearly 1,50,000 species identified, not more than a few hundred are interested in waging any war with humans. Those that do bother are, more often than not, innocent bystanders that get converted to criminality by circumstances beyond their control, to be condemned as opportunistic, a game that only humans play. Microbes labeled opportunistic need to be exculpated by rechristening them as opportunized, a status accorded to them by iatrogeny. They do not seek to invade; medical misdeeds force them to do so.

Anthropocentric medical science has failed to emphasize the truism that the microbial biomass outweighs the total animal biomass by a factor of 100 . Microbes are the HOST, we the pampered parasites. For every single of the 10,000 billion human cells, there are 10 microbes, so that an average human has on the body a microbial mass of at least $2 \mathrm{KG}$, the microbes numbering 100,000 billion. The human skin and nasopharyngeal and gastro-intestinal mucosae are lined by an inevitable, indispensable microbial sheet that is your parbiosis, comprising a milleu surferior (intermediate between milleu exterior and interior) that as a surfinsic layer protects your skin and mucosa by intermicrobial understanding whereby most of us sail through life without a bother. To denigrate these microbial gate-keepers as saprobes or saprophytes (Gk. sapros $=$ rotten, putrid), commensals, parasites, and worse, as pathogens is to forget that etymologically, they all comprise symbionts, meaning those that live together with you. Any microbe, that is your surfinsic neighbor, is a symbiont. The common peaceful coexistence with your microbial hosts is euparabiosis and quarrel is aneuparabiosis. It pays to bear in mind an aphorism enunciated by a text on internal medicine. Friendship between microbes and man is the rule and enmity an exception.

Enmity engendered by opportunized fungi is a consequence of antibiotically disturbed parabiosis and/ or immunosuppressively induced epitheliolysis. The foregoing, coupled with inevitable fungal proliferation to replace microbes eliminated by antibiotics, forces the fungi to travel into the depth of human tissues. A small but compound fracture has an infinitely greater chance of turning osteomyelitic than a large but closed fracture, proving that it is the intact skin cover, and not your antibiotics, that are the real protectors and preventors of deeper infection.

A medical idée fixe is that microbial opportunism is a gift of immunocompromise. The snag here is that immunologists themselves, amongst them the most important being the Nobel laureate Macfarlane Burnet, do not know whether immunity is a friend or a foe. Indeed, as Glemser the American sciencejournalist, summarized, the science of immunology is so advanced that one immunologist cannot make out what another is talking about. Medawar, the co-laureate with Burnet (vide supra), diagnosed that immunology suffers from 'bare-faced empiricism and embarrassingly 
silly terminology'. This is so because immunity (from $\mathrm{im}=$ not and munis $=$ service, meaning exemption from any duty or work) is yet to be defined so that while we go gaga over immunodeficiencies in AIDS, we keep on adding one disease after another as caused by immunity itself. Immunity, as of. 2007, is like the Big Brother in Orwell's 1984: 'tormentor, protector, inquisitor and friend'. The tissue destruction in leprosy/tuberculosis is now ascribed, not to the mycobacteria, but to the invasion that the patient's own immune system launches against the tissues that have the misfortune to house these rather inert, non-toxic microbes. Even the famed Burnetian idea of immunity eliminating cancerous clones puts paid by the suggestion that the so-called lymphocytic/immune proliferation around a cancerous focus serves as a fodder or forage for the cancer cells. Oh, Immunity, where is thy friendship? Oh, Microbes, where is your enmity?

Back to the fungi. Their decency resides in their readiness to respond to antibiotics like amphoterecin $\mathrm{B}$, and to surgical excision of the fungal SOLs. As the Handbook of Clinical Neurology, dealing selectively with infections of the nervous system (Volume 35, page 392), summarizes: 'Response to appropriate therapy is generally good, and cure rates around $90 \%$ or more, have been reported. It has been said that actinomycotic brain abscesses have a better prognosis than brain abscesses of other etiologies, perhaps because of the more indolent nature of the former'. A passage of good three dacades has not forced upon neurologists a different opinion.

What microbiologic-n-therapeutic lessons can neurology learn from Fungi? More faith in humility than in hubris. Given the host nature of microbes that shelter the human guest, it must be driven home that, Nature abhorring microbial vacuum, permits antibiotics to be mere microflorafluctuators that succeed in driving out some microbes to allow other 'pathogens' to take their place. Antibiotics, seen as a solution, have turned into a big problem. Raeburn of England, rued in the Lancet that 'In the years to come, the story of antibiotics may rank as Nature's most malicious trick' on mankind. Koprowski, participating in a Ciba Symposium, on Man and his future, 1968, issued a stern advice: 'If a universal antibiotic is found, immediately organize societies to prevent its use. It should be dealt with as we should have treated, and did not treat, the atomic bomb. Use any feasible national and international deterrent to prevent it falling into the hands of stupid people who probably will still be in majority in your time as they were in mine'. No wonder that antibiotics cause aneuparabiosis, to opportunize fungi into invading the human interior. Immunosupressors behave the same way, so that it is not so much the immune deficiency but the disturbed microbial flora, and compromised epithelia that account for mycosis in the so-called immunocompromized. The rarity of primary CNS mycosis, and the increasing frequency of the same in compromised individuals allow you to conclude that the fungi, vis-à-vis the CNS be declared as essentially innocent. Paul Davies, in his The Fifth Miracle traces our ancestory not to a monkey but to a microbe. The prokaryotic microbe turned eukaryotic fungus could have eventually begotten the eukaryotic human. No wonder, the joys of human fun-guys and fun-gals comes from the brew that the fungi cook, and the bread that the fungi bake. 